\title{
Respiration and growth of larval herring Clupea harengus: relation between specific dynamic action and growth efficiency
}

\author{
Thomas Kiørboe, Peter Munk, Katherine Richardson \\ Danish Institute for Fisheries and Marine Research, Charlottenlund Castle, DK-2920 Charlottenlund, Denmark
}

\begin{abstract}
Rates of growth and oxygen consumption were measured in larval herring Clupea harengus fed various rations (specific ingestion rate between 0 and $45 \%$ body wt $\mathrm{d}^{-1}$ ). Initially, growth increased linearily with ingestion. However, it showed a saturating response at high ingestion rates, probably caused by a decline in assimilation efficiency. Growth efficiency was expressed as slope of the linear portion of the growth-ingestion (or growth-assimilation) relationship. The efficiency by which ingested (or assimilated) material in excess of maintenance requirements was converted to larval body mass was high, 0.62 (or 0.89). compared to reported estimates in juvenile fish. The oxygen consumption rate $\left(\mathrm{R}, \mathrm{ng} \mathrm{O}_{2} \mathrm{~h}^{-1}\right)$ of anaesthetized larvae could be separated into two components, one proportional to the body mass ( $W, \mu g \mathrm{~d} w$ ) raised to some exponent $b$ and one component proportional to the growth rate $\left(\mu \times W, \mu g d w d^{-1}\right): R=131$ $\mathrm{W}^{0.68}+127 \mu \times \mathrm{W}$. At starvation, the respiration-mass relationship followed the commonly applied allometric equation and had a weight exponent close to the classical $2 / 3$. Growing larvae, however, increased their rate of oxygen uptake above the starvation level by ca $127 \mathrm{ng} \mathrm{O} \mathrm{O}_{2}$ per $\mu \mathrm{g}$ larval dry weight increment (= apparent metabolic cost of growth = specific dynamic action (SDA) expressed relative to growth). This empirical estimate was close to a theoretical minimum estimate of the cost of biosynthesis and transport but was in the lower range of the empirical values reported for juvenile fish. The observed SDA predicted a growth efficiency very close to that actually observed. The magnitude and composition of SDA. in larval and juvenile fish is discussed and it is concluded that the cost of growth is minimum and the efficiency of growth maximum in larval compared to juvenile fish. In an ecological context, this difference may be related to the very steep decline in natural mortality with increasing fish body mass and to the extraordinarily high mortality rates experienced by marine pelagic fish larvae in nature.
\end{abstract}

\section{INTRODUCTION}

The growth rate of an animal is determined by its rate of feeding, the efficiency by which ingested energy is assimilated in the gut, and by the energy expenditure of the animal, i.e. its metabolic rate. The efficiency by which assimilated energy in excess of maintenance requirements is converted into growth is, on the other hand, determined solely by the magnitude of the metabolic rate. Thus, when considering variations in growth efficiency, variations in metabolic rate are of particular interest. The metabolic rate of an animal varies with a number of factors, e.g. temperature, level of activity and rate of feeding. At constant temperature and activity, the variation in metabolic rate with ration determines the efficiency of growth.

It is well known that the metabolic rate of an animal increases in association with feeding. This phenome- non has been termed specific dynamic action, SDA. While SDA was formerly thought to be caused by the costs of feeding, digestion, deamination and ureasynthesis, it is now generally believed to mainly represent the cost of biosynthesis (e.g. Ashworth 1969, Jobling 1983, 1985, Vahl 1984, Kiørboe et al. 1985). Jobling (1985) considered SDA to be specifically related to growth and, implicitly, that SDA expressed relative to growth is constant. The implications of this hypothesis are (1) that the cost of growth may be determined from the covariation in growth and metabolic rate and (2) that the efficiency by which assimilated energy in excess of maintenance requirements is converted to body tissue (or reproductive output) is determined solely by this cost and is independent of e.g. body mass. Few studies have actually related metabolic rates to growth rates and the results of these are equivocal: estimates of SDA relative to growth vary by a factor of 
ca 6 (Jobling 1981, 1985, Vahl 1984, Kiørboe et al. 1985, Kiørboe \& Møhlenberg 1987). Considerations of sizedependent variations in growth efficiencies are likewise equivocal: while Paloheimo \& Dickie (1966) in their classical review of growth efficiencies in fish suggested that conversion efficiency was unrelated to body mass per se, Gerking (1971) documented a negative such relationship.

In this study, we examine the metabolic rate (measured as oxygen uptake) of larval herring in relation to feeding level and we estimate the magnitude of SDA. From the covariation in metabolic and growth rate, we estimate the apparent cost of growth and compare this to a theoretical estimate of cost of biosynthesis and to the estimated efficiency of growth from growth and ingestion experiments. Finally, we discuss the relationship between SDA, growth efficiency and body mass in larval and juvenile fish.

\section{MATERIAL AND METHODS}

Ripe females of herring Clupea harengus were obtained from the Clyde area (12 Mar 1986) and the Limfjord, Denmark (12 Apr 1986). Eggs from single females were fertilized with a mixture of sperm from several males and incubated in running seawater (ca $28 \%, 8^{\circ} \mathrm{C}$ ) and constant light for 16 to $18 \mathrm{~d}$ as described by Munk \& Rosenthal (1983). Upon hatching, 1500 yolk sac larvae were transferred to a thermostated stock tank of 800 (Clyde) or 200 l (Limfjord), with flow through of seawater $\left(28 \%, 8^{\circ} \mathrm{C}\right)$ and a diurnal rhythm of $14 \mathrm{~L}: 10 \mathrm{D}$. Subsamples of yolk sac larvae were analysed for dry weight, $\mathrm{C}$ - and $\mathrm{N}$-content (Perkin Elmer $\mathrm{CHN}$-analyser). From the time of first feeding, stock larvae were fed nauplii $\left(360 \mathrm{l}^{-1} \approx 55 \mu \mathrm{g} \mathrm{Cl}^{-1}\right)$ and later copepodites $\left(120 \mathrm{l}^{-1} \approx 52 \mu \mathrm{g} \mathrm{C}^{-1}\right)$ of Acartia tonsa cultivated in the laboratory (Støttrup et al. 1986). At these concentrations, neither ingestion (Munk \& Kiørboe 1985) nor growth rate (Kiørboe \& Munk 1986) is limited by food availability.

Growth and ingestion. All 6 experimental series were conducted with larvae ranging in age and weight from 10 to $75 \mathrm{~d}$ and 100 to $10000 \mu \mathrm{g} \mathrm{dw}$, respectively. For each experimental series, larvae were taken from the stock tank. Ca 25 'stock larvae' were used for respiration measurements (see below) and subsequently measured individually for standard (live) length and dry weight. Pooled samples were analysed for $\mathrm{C}$ and $\mathrm{N}$ content.

Seventeen to 50 larvae were distributed in each of four $200 \mathrm{l}$ experimental tanks where environmental conditions were identical to those in the stock tanks. Here, they were either starved or fed nauplii (one experiment) or copepodites (all other experiments) at ca 5,15 or $45 \%$ of the body wt $\mathrm{d}^{-1}$ during 6 to $10 \mathrm{~d}$. The nominal feeding levels were determined from lengthweight regressions of larvae and copepods obtained in previous experiments at our laboratory (e.g. Kiørboe \& Munk 1986, Berggren \& Hansen 1987), whereas the actual ingestion rates were estimated as described below. In most experiments, the larvae were not able to feed at a rate equal to $45 \% \mathrm{~d}^{-1}$. In such cases, crude estimates of ingestion rate (number added minus remaining copepods after $24 \mathrm{~h}$ ) were made at the beginning of an experiment and the addition of food was regulated downwards in all tanks to avoid accumulation of copepodites and to conserve differences between feeding levels. To allow for growth of larvae, the addition of food was subsequently increased by 0 to $10 \% \mathrm{~d}^{-1}$ during the remainder of the experiment. At the termination of an experiment, remaining nauplii or copepodites were counted and the ingested food' calculated as the difference between added and remaining food. Control experiments showed that 'natural' mortality of copepods was negligible during the experimental period. The respiration rate of the larvae was recorded (see below) and their length, dry weight, $\mathrm{C}$ and $\mathrm{N}$ content measured. Each day, the length of the copepodites/nauplii was measured and the average $\mathrm{C}$ and $\mathrm{N}$ content of the food calculated from length- $\mathrm{N}$ regressions and $\mathrm{C}: \mathrm{N}$ ratio (Table 1 ; this table was derived from data in Berggren \& Hansen

Table 1. Acartia tonsa. Estimates of parameters and their $95 \%$ confidence limits in dobb. log regressions of body weight ( $W$, ng $N$ ) versus body length (nauplii) or cephalothorax length (copepodites) ( $\mathrm{L}_{1}$ um) of $A$. tonsa used as food: $\ln W=\ln \mathrm{a}+\mathrm{b}$ In L. $\mathrm{n}=$ number of observations. $\mathrm{C}: \mathrm{N}$ indicates carbon to nitrogen ratio

\begin{tabular}{|ccccc|}
\hline & $\ln \mathrm{a}$ & $\mathrm{b}$ & $\mathrm{n}$ & $\mathrm{r}^{2}$ \\
\hline Nauplii & $-14.30 \pm 0.43$ & $3.35 \pm 0.09$ & 28 & 0.90 \\
Copepodites & $-13.30 \pm 0.25$ & $3.00 \pm 0.04$ & 28 & 0.97 \\
C:N ratio $\pm 95 \%$ CL: $4.1 \pm 0.1$ & & & \\
\hline
\end{tabular}

1987). Daily specific growth rates were estimated as the weight increment divided by average weight $\left(W_{0}+W_{t}\right) / 2$ and duration of experiment. Daily specific ingestion rates were calculated as the cumulative amount of nitrogen ingested divided by number of larval days and average larval nitrogen content. Larval mortality was low $\left(0\right.$ to $\left.3 \% \mathrm{~d}^{-1}, \bar{x}=1.4 \% \mathrm{~d}^{-1}\right)$. For the purpose of the ingestion calculation, deceased larvae were assumed to have died at the middle of the experimental period.

Respiration rate. Rate of oxygen consumption was measured on anaesthetized larvae. Prior to measurement, larvae were submerged for ca $5 \mathrm{~min}$ in a $2 \%$ 
Propanidid solution. Since this anaesthetic does not act depressively on the respiration centre (Siwicki 1984) it was selected in preference to the frequently employed MS-222. If returned to clean water, the larvae would resume swimming activity within a few minutes. One to 5 larvae were incubated in a closed 1.5 to $2 \mathrm{ml}$ chamber filled with oxygen-saturated water and submerged in a temperature-controlled water bath $\left(8^{\circ} \mathrm{C}\right)$. Turbulence was created in the chamber with a magnetic stirrer that was separated from the larvae by a coarse mesh. After ca $1 \mathrm{~h}$ of incubation, a sample $(0.5 \mathrm{ml})$ was withdrawn from the chamber by means of a peristaltic pump connected serially to a temperaturecontrolled oxygen electrode (Radiometer, E5046). The electrode was allowed to equilibrate for $5 \mathrm{~min}$, and the oxygen tension was recorded (Radiometer PHM 73). The decrease in oxygen saturation was normally 5 to $10 \%$ and never more than $20 \%$. Blank measurements were made without larvae in the chamber and were run between every 2 to 4 measurements. Chamber respiration was normally low but values corresponding to up to $20 \%$ of the respiration rate were accepted. Tubes and chambers were rinsed in alcohol and distilled water between every measurement. The rate of oxygen uptake was calculated from the decrease in oxygen content (blank corrected), taking temperature, salinity and pressure into consideration, multiplied by chamber volume and divided by incubation time and number of larvae.

\section{RESULTS}

\section{Carbon and nitrogen content}

Carbon and nitrogen content, as well as the $\mathrm{C}: \mathrm{N}$ ratio, of post yolk sac herring larvae increased slightly, but insignificantly ( 1 -way ANOVA, $p>0.1$ ), with feeding level (Table 2). Recently hatched yolk sac larvae, on the other hand, had significantly lower $\mathrm{N}$ and higher

Table 2. Clupea harengus. Average ( $\pm 95 \% \mathrm{CL}$ ) carbon content $(\mathrm{C} \%)$, nitrogen content $(\mathrm{N} \%)$ and $\mathrm{C}: \mathrm{N}$ ratio at various feeding levels

\begin{tabular}{|lcccr|}
\hline $\begin{array}{l}\text { Feeding } \\
\text { level }\end{array}$ & $\mathrm{C} \%$ & $\mathrm{~N} \%$ & $\mathrm{C}: \mathrm{N}$ & $\mathrm{n}$ \\
\hline $\begin{array}{l}\text { Yolk sac } \\
\text { larvae }\end{array}$ & $47.8 \pm 1.3$ & $10.5 \pm 0.6$ & $4.54 \pm 0.37$ & 4 \\
Starvation & $43.2 \pm 0.8$ & $11.5 \pm 0.3$ & $3.75 \pm 0.05$ & 13 \\
$5 \%$ & $44.3 \pm 1.1$ & $11.9 \pm 0.5$ & $3.74 \pm 0.07$ & 10 \\
$15 \%$ & $45.0 \pm 1.3$ & $11.7 \pm 0.3$ & $3.82 \pm 0.07$ & 10 \\
$45 \%$ & $45.4 \pm 1.3$ & $11.8 \pm 0.2$ & $3.86 \pm 0.05$ & 10 \\
Stock & $44.9 \pm 1.5$ & $11.6 \pm 0.4$ & $3.87 \pm 0.08$ & 9 \\
Overall & $44.5 \pm 0.4$ & $11.7 \pm 0.1$ & $3.82 \pm 0.03$ & 52 \\
\hline
\end{tabular}

$\mathrm{C}$ and $\mathrm{C}: \mathrm{N}$ than post yolk sac larvae (non-overlapping confidence limits, Table 2). The $C: N$ ratio of the experimental post yolk sac larvae was similar to the $C: N$ ratio of the copepods used as food, 3.8 and 4.1 , respectively (Tables $1 \& 2$ ). These data suggest that (1) yolk sac larvae preferentially metabolize lipid and utilize protein for growth and (2) post yolk sac larvae metabolize body constituents roughly in proportion to their occurrence during short periods of starvation. Thus, post yolk sac herring larvae do not form significant lipid energy stores but rather channel ingested matter into growth. Finally, in the present experiments, ingested protein, lipid and carbohydrates are metabolized or channelled into growth in proportion to their occurrence in the diet. Calculations of specific growth and ingestion rates are, therefore, largely independent of the unit used ( $C, N$ or calories), and we use nitrogen in the following presentation.

\section{Growth and ingestion rates}

Specific growth rates of larvae fed with the maximum ration ('stock' and ' $45 \%$ ') and of a body weight less than 2 to $3 \mathrm{mg} \mathrm{dw}$ were independent of body mass and only the largest larvae showed a depressed growth rate (Fig. 1). There was a slight overall negative, but insignificant, correlation between specific growth rate and body mass $(\mathrm{r}=-0.51 ; 0.1>\mathrm{p}>0.05)$. The same is true for specific ingestion rate $(\mathrm{r}=-0.49)$. Growth rates were similar for Clyde and Limfjord larvae (Fig. 1).

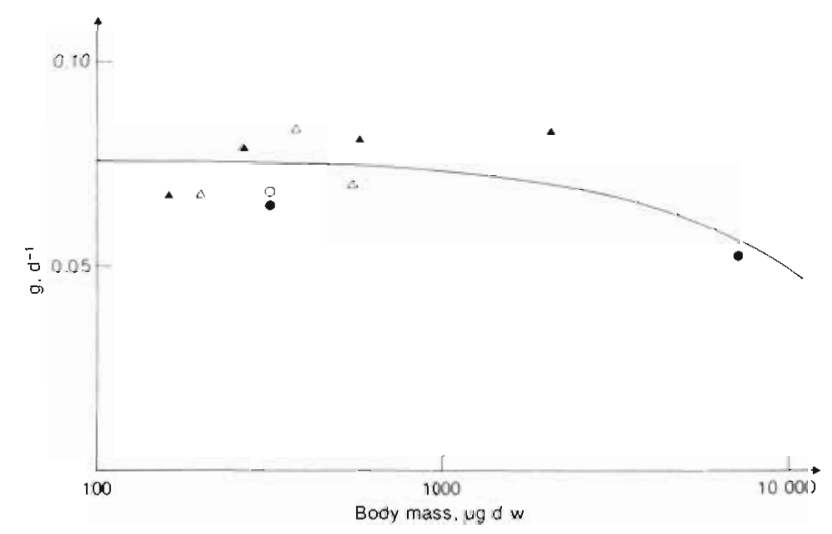

Fig. 1. Clupea harengus. Maximally recorded specific growth rates $\left(g, d^{-1}\right)$ of larvae as a function of body mass ( $W, \mu g \mathrm{dw}$ ). Note that body mass is on a logarithmic scale. Open symbols: 'stock' larvae; closed symbols: '45\%' larvae; triangles: Limfjord larvae; circles/dots: Clyde larvae. Regression line is $\mathrm{g}=$ $0.077-0.28 \times 10^{-5} \mathrm{~W}\left(\mathrm{r}^{2}=0.26\right)$

Specific growth rate increased with specific ingestion rate in a decelerating manner and approached a plateau asymptotically (Fig. 2). The relation between 


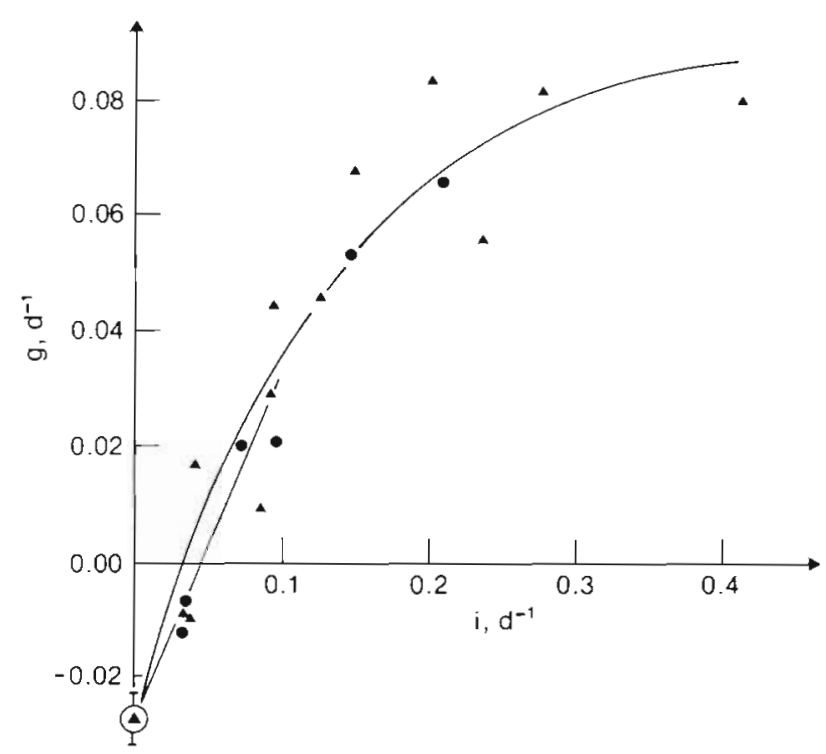

Fig. 2. Clupea harengus. Specific growth rates $\left(g, d^{-1}\right)$ as a function of specific ingestion rate $\left(i, d^{-1}\right)$. Triangles: Limfjord larvae; dots: Clyde larvae. Parameters of regression curves given in Table 3

growth and ingestion was independent of variations in body mass over the experimental range, and all data were, therefore, treated together.

The data were fitted to the equation

$$
g=K\left(1-e^{-\beta i}\right)-r_{0},
$$

where $g$ and $i=$ specific daily growth and ingestion rates; $K, \beta$ and $r_{0}=$ constants. Parameter estimates and their confidence limits are given in Table 3 . The ordinate intercept $\left(r_{0}\right)$ is an estimate of the specific starvation metabolic rate, the intercept with the abcissa $(=0.036)$ is an estimate of the specific maintenance

Table 3. Clupea harengus. Estimation of parameters $195 \%$ confidence interval in parentheses) in various models. $g=$ specific growth rate $\left(d^{-1}\right), i=$ specific ingestion rate $\left(d^{-1}\right), \mu=$ specific growth rate relative to starving larvae $\left(=g+g_{0}\right), r=$ oxygen uptake (ng $\mathrm{O}_{2} \mathrm{~d}^{-1}$ ), $\mathrm{W}=$ body mass ( $\mu \mathrm{g} \mathrm{d} w$ ). $\mathrm{K}, \beta, \alpha \mathrm{O}$, $a, b$, and $a^{\prime}$ are parameters to be estimated. $n=$ number of observations, $\mathrm{I}^{2}=$ coefficient of determination. See Fig. $2 \& 5$ for graphical presentation

\begin{tabular}{|c|c|c|c|}
\hline Model & Parameter estimates & $\mathrm{n}$ & $r^{2}$ \\
\hline $\begin{array}{l}g=K\left(1-e^{-\beta 1}\right)-r_{0} \\
(E q \cdot 1) \\
g=\beta K i-r_{0} \\
(i<0.1)\end{array}$ & $\begin{array}{l}K=0.12 \quad(0.10-0.14) \\
\beta=7.6 \quad(4.9-10.4) \\
r_{0}=0.029(0.022-0.036) \\
\beta K=0.62 \quad(0.59-0.65) \\
r_{0}=0.027 \quad(0.26-0.28)\end{array}$ & 25 & 0.95 \\
\hline $\begin{array}{l}\mathrm{R}=\mathrm{a} \mathrm{W}^{\mathrm{b}}+\mathrm{a}^{\prime} \mu \mathrm{W} \\
\text { (Eq. 3) }\end{array}$ & $\begin{array}{l}a=131 \quad(93-168) \\
b=0.68(0.65-0.73) \\
a^{\prime}=127 \quad(117-137)\end{array}$ & 26 & 0.998 \\
\hline
\end{tabular}

ration $(g=0), K-r_{0}$ is an estimate of the maximum growth rate and the slope

$$
\frac{\mathrm{dg}}{\mathrm{di}}=\beta \mathrm{K} \mathrm{e}^{-\beta \mathrm{i}}
$$

is an estimate of the efficiency by which additional ingested matter (in the interval $\mathrm{i}$ to $\mathrm{i}+\mathrm{di}$ ) will be channelled into growth. Since the estimates of $\beta$ and $K$ are strongly positively intercorrelated $(r=0.92)$, the estimate of the initial slope $(=\beta \mathrm{K}$ for $\mathrm{i}=0)$ will be subject to considerable uncertainty (large confidence limits). From Fig. 2, it can be seen that the initial slope is actually overestimated. Therefore, to estimate the slope of the nearly linear, initial part of the curve $(\beta K)$, a linear regression was alternatively made using only data where $i<0.1$ (Table 3 ). The slope of this regression $(0.62)$ is an estimate of the efficiency by which ingested matter in excess of maintenance requirements is channelled into growth (for $\mathrm{i}<0.1$ ).

\section{Respiration relative to growth and body mass}

Since respiration rates relative to body mass in 'stock' and ' $45 \%$ ' larvae did not differ significantly, they were pooled (Fig. 3). Clyde and Limfjord larvae were also treated together since their respiration rates were indistinguishable from one another. In Fig. 4 regression lines for 'starved', '5\%', '15\%' and ' $45 \%$ ' larvae are compared and the estimated parameters of the logarithmic regressions are given in Table 4 . The respiration rate of 'stock' and ' $45 \%$ ' larvae exceeded the respiration rate of starved larvae by a factor of 1.4 to 2.1 , and ' $5 \%$ ' and ' $15 \%$ ' larvae showed intermediate respiration rates (Fig. 4, Table 4). The slope (power) of the allometric respiration-body mass relation for starved larvae differed significantly from those of the feeding/growing larvae $(p<0.05)$, whereas the slopes did not vary significantly between different groups of feeding larvae. The estimates of the slopes for growing/ feeding larvae are influenced by variations in specific growth or ingestion rates with body mass. The entire data set was treated in a common model:

Table 4. Clupea harengus. Estimates of parameters $( \pm 95 \%$ $C L)$ in regressions of ln oxygen uptake $\left(R, n g \mathrm{O}_{2} \mathrm{~h}^{-1}\right)$ versus $\ln$ body mass ( $W, \mu g d w$ ) at various feeding levels: $\ln R=\ln a+b$ In $\mathrm{W} . \mathrm{n}=$ number of observations, $\mathrm{r}^{2}=$ coefficient of determination. See also Fig. 3

\begin{tabular}{|lcccc|}
\hline Feeding level & $\ln \mathrm{a}$ & $\mathrm{b}$ & $\mathrm{n}$ & $\mathrm{r}^{2}$ \\
\hline Starvation & $1.38 \pm 0.06$ & $0.74 \pm 0.01$ & 53 & 0.90 \\
$5 \%$ & $1.13 \pm 0.05$ & $0.81 \pm 0.01$ & 44 & 0.96 \\
$15 \%$ & $1.35 \pm 0.05$ & $0.80 \pm 0.01$ & 45 & 0.96 \\
$45 \%+$ stock & $1.47 \pm 0.02$ & $0.82 \pm 0.01$ & 87 & 0.97 \\
\hline
\end{tabular}


Fig. 3. Clupea harengus. Allometric relaand body mass ( $\mu \mathrm{g} \mathrm{dw}$ ) of 'stock' and ' $4.5 \%$ ' larvae. Symbols as for Fig. 1. Paration between oxygen uptake (ng $\mathrm{O}_{2} \mathrm{~h}^{-1}$ ) meters of regression line given in Table 4
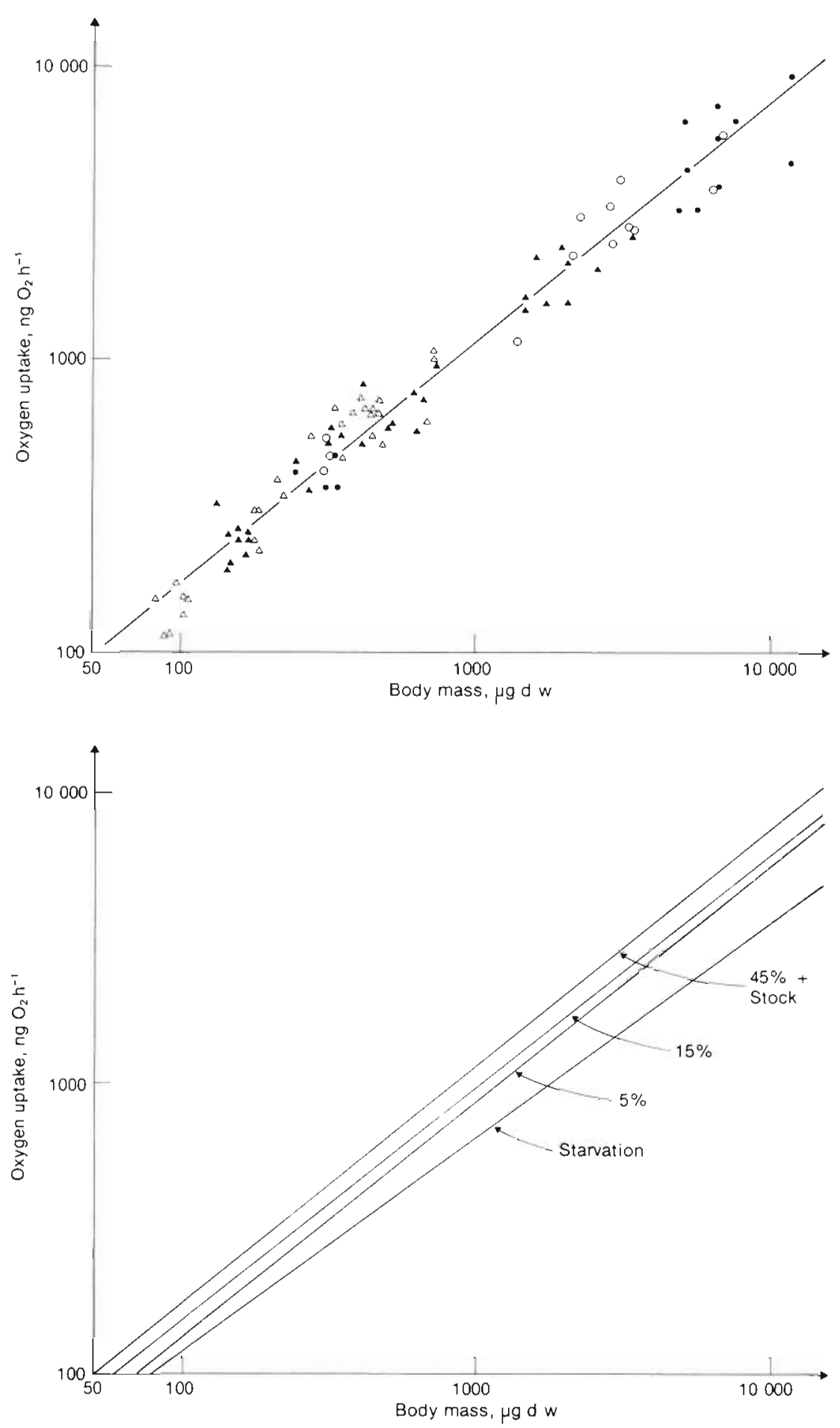

(3)

$$
R=a W^{b}+a^{\prime} \mu W
$$

stating that the respiration rate (R) is equal to a component proportional to body mass raised to some power b (starvation respiration) plus a component proportional to the growth rate measured relative to the weight loss at starvation $\left(\mu=\mathrm{g}+\mathrm{g}_{0}\right.$, where $g_{0}=$ specific growth rate of the appropriate starvation control); $a^{\prime}$ is an estimate of specific dynamic action (SDA) expressed relative to biomass increment, and, thus represents the apparent, metabolic cost of growth. Since specific growth rates have only been obtained for populations of larvae, averages of $\mathrm{R}\left(\mathrm{ng} \mathrm{O}_{2} \mathrm{~d}^{-1}\right)$ and $\mathrm{W}$ 


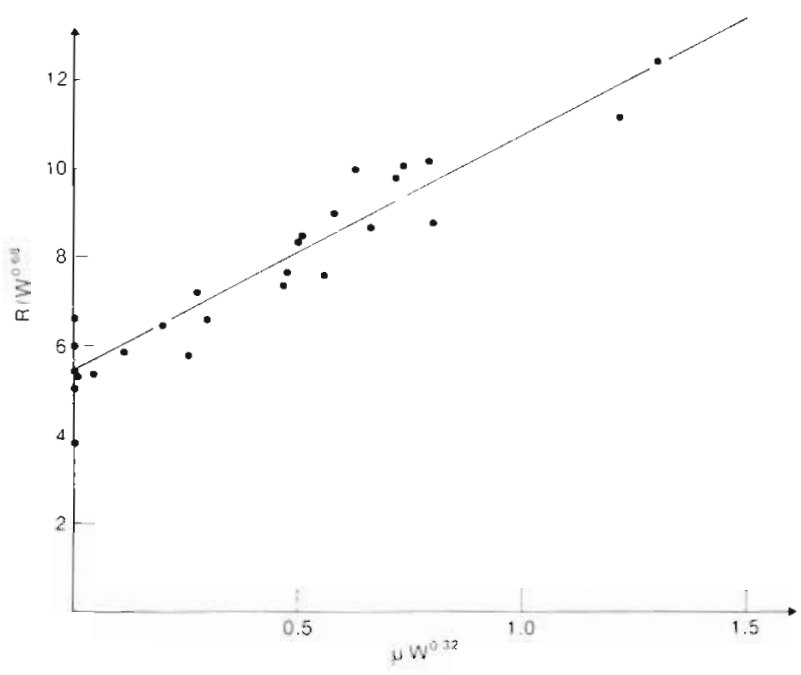

Fig. 5. Clupea harengus. Graphical illustration of the effect of growth on oxygen uptake, cf. Eq. 3 and Table $3 . \mathrm{R}=$ oxygen uptake, ng $\mathrm{O}_{2} \mathrm{~h}^{-1} \mathrm{~W}=$ body mass, $\mu \mathrm{g} \mathrm{dw} ; \mu\left\{=\mathrm{g}+\mathrm{go}_{\mathrm{o}}\right\}=$ specific growth rate expressed relative to weight loss at starvation, $\mathrm{d}^{-1}$

(ug) for each treatment have been used as input to the model. Table 3 gives the estimates of the parameters $a_{1}$ $\mathrm{b}$ and $\mathrm{a}^{\prime}$ (least square fit) and Fig. 5, a graphical representation of the growth component of the fit. The estimate of $\mathrm{a}^{\prime}$ indicates that some $130 \mathrm{ng} \mathrm{O}_{2}$ are consumed for each $\mu \mathrm{g}$ of biomass deposited. The estimates of $a$ and $b$ in Ec. 3 do not deviate significantly from the estimates of $a$ and $b$ for starving larvae (overlapping confidence limits, compare Fables 3 \& 4).

The present estimates of respiration by anaesthetized larvae are not considered representative for the active larvae in the experimental tanks but are thought to represent the respiration of inactive larvae. A term dependent on locomotor activity should be added to the above equation to describe respiration rates of freely swimming larvae.

\section{DISCUSSION}

\section{Growth and ingestion}

The $g-i$ relationship for herring larvae found in the present study compares well with that found by Checkley (1984) for the same species and for larval fish in general. Checkley (1984) compiled data on $g$ and $i$ for different species of fish larvae $\left(8^{\circ} \mathrm{C}\right)$ and fitted them into a general relationship:

$$
g=0.13+0.088 \log _{10} i
$$

Our data fit equally well into a relationship of this form and yield similar estimates of the parameters $\left(g=0.13+0.090 \log _{10} i, r^{2}=0.89\right)$. However, Checkley's model is not defined for $i=0$ ( $g$ actually approaches $-\infty$ as $i$ approaches 0 ), and it is only descriptive since the parameters cannot be interpreted in biological terms.

The saturating response of growth with respect to ingestion is probably caused by a decrease in the efficiency by which ingested material is assimilated by the larva as i increases. Thus, Boehlert \& Yoklavich (1984) found that the efficiency by which herring larvae assimilated Artemia nauplii decreased exponentially with food concentration. Since the functional response of larval herring to concentration of food resembles a Holling type II response (Munk \& Kiørboe 1985), the relationship between assimilation efficiency $(\alpha)$ and ingestion may be approximated by

$$
\alpha=\alpha_{0} \frac{\left(1-e^{-\beta i}\right)}{\beta \mathbf{i}},
$$

where $\alpha_{0}=$ assimilation efficiency at low (zero) ingestion rate; $\beta=$ a constant. Growth is the difference between assimilation (a) and metabolism (r), hence

$$
g=a-r
$$

Since respiration increases in proportion to $g$ and, hence, to a then

$$
\mathrm{r}=\gamma \mathrm{a}+\mathrm{r}_{0}
$$

and

$$
g=(1-\gamma) \mathrm{a}-\mathrm{r}_{0}
$$

where $\mathrm{r}_{0}=$ specific metabolic rate at starvation; $\gamma$ $(=\mathrm{dr} / \mathrm{da}=1-\mathrm{dg} / \mathrm{da})=$ the specific dynamic action expressed relative to assimilation. Combining Eqs. 4 \& 6 a yields

$$
g=\frac{(1-\gamma) \alpha_{0}}{\beta}\left(1-e^{-\beta i}\right)-r_{0}
$$

$$
\text { Letting } \quad \mathrm{K}=\frac{(1-\gamma) \alpha_{0}}{\beta}
$$

and inserting into Eq. 7 yields Eq. 1, which was used to describe the relationship between $g$ and $i$ in the present study. All the parameters may be interpreted in biological terms, which we will utilize below

The data on growth and ingestion rate of herring larvae presented by Kiørboe \& Munk (1986) fitted badly into both of the proposed models. We now believe that $i$ was overestimated in that study, as also suggested by Kiørboe \& Munk (1986). The discrepancies in $\mathrm{dg} / \mathrm{di}$ between large (high $\mathrm{dg} / \mathrm{di}$ ) and small (low dg/di) larvae in the data of Kiorboe \& Munk (1986) were probably caused by the higher specific ingestion rates (up to $0.63 \mathrm{~d}^{-1}$ ) obtained by the small 
larva, since a linear $\mathrm{g}-\mathrm{i}$ relationship was applied to the data. The present data suggest that $\mathrm{dg} / \mathrm{di}$ declines with increasing $i$.

\section{Efficiency of growth}

Growth efficiencies are often expressed as the ratio of growth to ingestion $(\mathrm{g} / \mathrm{i}=$ gross growth efficiency [GGE]) or as the ratio of growth to assimilation ( $\mathrm{g} / \mathrm{a}=$ net growth efficiency [NGE]). These efficiencies, however, depend strongly on the ingestion or the assimilation rate. This dependency has seriously obscured considerations of size dependent variation in growth efficiency. We, therefore, prefer to express growth efficiency as the slope of the $\mathrm{g}-\mathrm{i}(\mathrm{dg} / \mathrm{di})$ or the $g-a(d g / d a)$ relationship. GGE will approach $\mathrm{dg} /$ di and NGE dg/da asymptotically as i or a increases. For the linear portion of the $g-i$ relationship, dg/di is independent of $\mathrm{i}$ and we estimate, by linear regression, a slope of $0.62(\beta \mathrm{K})$. Our estimate is similar to that found by Checkley (1984) for herring larvae, 0.59 .

Since herring larvae fit into Checkley's general $\mathrm{g}^{-\mathrm{i}}$ relationship for larval fish, this estimate is probably representative for fish larvae in general. However, $\mathrm{dg} / \mathrm{di}$ estimated for the linear portion of the $\mathrm{g}-\mathrm{i}$ relation in juvenile fish is generally somewhat lower and tends to decrease with increasing body mass. Thus, Gerking (1971) found that dg/di declined from 0.44 in small to 0.14 in large $(\mathrm{r}=-0.96)$ juvenile bluegill sunfish Lepomis macrochirus. He also compiled literature data that showed similar magnitudes of $\mathrm{dg} / \mathrm{di}$ and the same negative relationship to body mass in juvenile fish of other species.

This discrepancy in $\mathrm{dg} / \mathrm{di}$ between larval and juvenile fish and its apparent relationship to body mass are probably not caused by differences in assimilation efficiency. The efficiency of assimilation in larval fish is similar to (or less than) that in juveniles and invariable with body size (see review by Govoni et al. 1986). Accordingly, the same negative relationship to body mass is also evident when considering variations in $\mathrm{dg} / \mathrm{da}$, the efficiency by which assimilated matter in excess of maintenance requirements is channelled into growth. For the present data set, dg/da may be estimated as $\mathrm{dg} / \mathrm{di} \times(\mathrm{da} / \mathrm{di})^{-1}$. Since

$$
\mathrm{a}=\alpha \mathrm{i}
$$

it follows by inserting Eq. 8 into Eq. 4, differentiating, and dividing into Eq. 2 that

$$
\frac{\mathrm{dg}}{\mathrm{da}}=\frac{\beta \mathrm{K}}{\alpha_{0}}
$$

$\mathrm{dg} / \mathrm{da}$ is constant and independent of ingestion or assimilation rate over the entire range. Boehlert \& Yoklavich (1984) estimated $\alpha_{0}=0.7$ for herring larvae feeding on Artemia nauplii. If $\beta \mathrm{K}=0.62$, then $\mathrm{dg} / \mathrm{da}$ may be estimated as 0.89 .

Values of $\mathrm{dg} / \mathrm{da}$ reported for juvenile fish are lower than the present estimate. On the basis of his own measurements and literature data, Birkett (1969) estimated $\mathrm{dg} / \mathrm{da}$ for juveniles of a variety of fish species ( 0.1 to $100 \mathrm{~g}$ live weight) and found values between 0.28 and 0.76 . Variations in $\mathrm{dg} / \mathrm{da}$ within species were negatively related to body mass.

Thus, the growth efficiency in larval herring, expressed either as $\mathrm{dg} / \mathrm{di}$ or $\mathrm{dg} / \mathrm{da}$, is considerably higher than reported for juvenile fish and efficiencies of growth tend generally to decline with body mass in fish. The same trend is well documented for growth efficiencies when expressed as GGE or NGE both in fish (e.g. Paloheimo \& Dickie 1966) and aquatic invertebrates (e.g. Jørgensen 1976). However, the above conclusion is not implicit in this observation due to sizedependent variations in maintenance requirement and specific ingestion rate. Actually, Paloheimo \& Dickie (1966) considered size-dependent variation in GGE to be caused by variation in specific ingestion rate rather than a function of body mass per se. The present observations contradict this conclusion.

\section{SDA and efficiency of growth}

The relationship between growth efficiency (dg/da) and SDA expressed relative to either assimilation (dr/da) or growth (dr/dg) may be obtained by differentiation of Eq. 5 with respect to a:

$$
\frac{\mathrm{dr}}{\mathrm{da}}+\frac{\mathrm{dg}}{\mathrm{da}}=1
$$

and

$$
\frac{\mathrm{dr} / \mathrm{da}}{\mathrm{dg} / \mathrm{da}}=\mathrm{dr} / \mathrm{dg}
$$

This set of equations quantifies how variations in $\mathrm{dr} / \mathrm{dg}$ or $\mathrm{dr} / \mathrm{da}$ dictate variation in $\mathrm{dg} / \mathrm{da}$ (or vice versa) and, as long as the assimilation efficiency is constant, in $\mathrm{dg} f$ di. In this paper, we have expressed SDA in relation to growth as we consider SDA to be closely related to the cost of biosynthesis (cf. Jobling 1983, Kiørboe et al. 1985). We found that ca $130 \mathrm{ng} \mathrm{O}$ are consumed for every $\mu \mathrm{g}$ of larval weight increment (Table 3 ). As a dimensionless coefficient, $\mathrm{dr} / \mathrm{dg}$, this corresponds to ca 0.10 . This estimate of $\mathrm{dr} / \mathrm{dg}$ for herring larvae leads to 
an estimate of growth efficiency, dg/da, of 0.91 (Eqs. 9 \& 10). This fits nicely with the independent estimate of $\mathrm{dg} / \mathrm{da}=0.89$ based on growth and ingestion measurements as described above. Thus, our data are internally consistent.

Since published estimates of growth efficiency $(\mathrm{dg} / \mathrm{di}$ or $\mathrm{dg} / \mathrm{da}$ ) suggest that larvae are superior to juvenile fish and that growth efficiency tends to decline with body mass, we would expect the opposite trend for both $\mathrm{dr} / \mathrm{dg}$ and $\mathrm{dr} / \mathrm{da}$ according to Eqs. 9 \& 10.

Accounts of $\mathrm{dr} / \mathrm{dg}$ are few in the literature, since growth and respiration rates are seldom measured simultaneously. However, those that do exist seem to suggest a higher dr/dg for juvenile than for larval fish and small aquatic invertebrates. For developing herring embryos (in the egg) Kiørboe \& Møhlenberg (1987) found, by independent methods, a value similar to the present estimate $\left(130\right.$ to $150 \mathrm{ng} \mathrm{O}_{2}$ per $\mu \mathrm{g} \mathrm{dw}$ increment, $\mathrm{dr} / \mathrm{dg}=0.10$ to 0.12 ). Kiørboe et al. (1985) reported $\mathrm{dr} / \mathrm{dg}=0.19(\mathrm{C} / \mathrm{C})$ for the copepod Acartia tonsa. Jobling (1981) compiled data on juvenile sockeye salmon Oncorhynchus nerka and estimated that ca $350 \mathrm{ng}$ of oxygen were consumed for each $\mu \mathrm{g}$ of weight increment (dr/dg 0.27). Jobling (1985), recalculating data on juvenile African catfish Clarias lazera (1.6 to $92 \mathrm{~g} \mathrm{dw}$ ) presented by Hogendoorn (1983), found $\mathrm{dr} / \mathrm{dg}$ $\sim 0.43$ to 0.60 (390 to $550 \mathrm{ml}$ oxygen per $\mathrm{mg} \mathrm{dw}$ gain). Finally, we recalculated the data of From \& Rasmussen (1984) on juvenile rainbow trout Salmo gairdneri and found $\mathrm{dr} / \mathrm{dg}$ to vary between 0.19 and 0.27 .

The present estimate of $\mathrm{dr} / \mathrm{da}(=0.09$, from Eqs. 9 \& $10)$ is also in the lower range of those reported for aquatic invertebrates and juvenile fish. Estimates of $\mathrm{dr} /$ $\mathrm{da}$ (frequently termed the SDA-coefficient) range between 0.1 and 0.35 (e.g. Jobling 1981, Soofiani \& Hawkins 1982, Abou Debs 1984, Kiørboe et al. 1985, Lampert 1986). The observed variation in $\mathrm{dr} / \mathrm{da}$ for larval and juvenile fish is consistent with the observed range of $\mathrm{dr} / \mathrm{dg}(0.1$ to 0.6 , cf. Eqs. $9 \& 10)$. This variation may, in part, be attributed to variation in the composition of the diet (see below) and, in part, to variation in body mass. However, direct determinations of the relationship between $\mathrm{dr} / \mathrm{da}$ (or $\mathrm{dr} / \mathrm{di}$ ) and body mass are few and the results are conflicting. Tandler \& Beamish (1981) found that dr/di was independent of body mass ( 5 to $250 \mathrm{~g}$ ) in largemouth bass Micropterus salmoides, whereas Smith (1973) observed a direct relationship between $\mathrm{dr} / \mathrm{da}$ and body mass in the saragassum fish Histrio histrio ( 1 to $28 \mathrm{~g}$ ).

In conclusion, available information suggest that growth efficiency is high and the apparent cost of growth (dr/dg) low in larval compared to juvenile fish and that there is a tendency of increasing cost and decreasing efficiency of growth with increasing body mass.

\section{Magnitude and composition of SDA}

It is possible to calculate a theoretical minimum value of $\mathrm{dr} / \mathrm{dg}$ by considering the cost of biosynthesis and transport. Herring larvae of 10 to $25 \mathrm{~mm}$ length consist of ca $70 \%$ protein, $4 \%$ carbohydrates, and $5 \%$ triglycerides in addition to ash (Erlich 1974). Three to 5 molecules of adenosine triphosphate (ATP) are required to form a peptide bond (e.g. Grisolia \& Kennedy 1966, Stouthamer 1973, Müller \& Kirchgessner 1979). Since the molecular weight of an average amino acid is ca 112 , then $(0.70 / 112) \times 3$ to $5=19$ to 31 $\times 10^{-3} \mathrm{~mol}$ ATP are required to synthesize the protein contained in $1 \mathrm{~g}$ of larval tissue. Similarly, triglycerid and carbohydrate formation require 0.06 and $0.5 \times$ $10^{-3}$ mol ATP per $g$ of larval tissue, respectively (see Kiørboe et al. 1985 for a further elucidation of this approach). Thus, the cost of biosynthesis totals 19.5 to $31.5 \times 10^{-3} \mathrm{~mol}$ ATP per $\mathrm{g} d w$ formed. The transport of fatty acids is free, whereas ca $1 \mathrm{~mol}$ ATP is required to transport $1 \mathrm{~mol}$ amino acid or monosaccharid (see Kiørboe et al. 1985). Hence, $[(0.70 / 112) \times 1+(0.04 / 162)$ $\times 1]=6.5 \times 10^{-3} \mathrm{~mol}$ ATP per $\mathrm{g}$ dry mass formed is required for transport processes, and 26 to $38 \times 10^{-3}$ mol ATP per $g \mathrm{dw}$ increment is, thus, an estimate of the total cost of growth. In terms of oxygen consumption, this corresponds to 145 to $210 \mathrm{ng} \mathrm{O}_{2}$ per $\mu \mathrm{g}$ dry weight formed, or $\mathrm{dr} / \mathrm{dg}=0.11$ to 0.16 .

This estimate, of course, depends on the composition of the deposited biomass. However, in this respect, herring larvae are probably representative for growing aquatic animals in general. The only exception is animals that, for whatever reason, deposit lipids. In the extreme case, where food, metabolized matter and deposited biomass is pure lipid, the theoretical estimate of $\mathrm{dr} / \mathrm{dg}$ is ca 0.02. Larvae and juvenile animals normally do not build energy stores but, like herring larvae, allocate ingested energy into 'true' growth.

Estimates of $\mathrm{dr} / \mathrm{dg}$ for small animals (i.e. herring larvae, herring embryos, the copepod Acartia tonsa; body masses $<10 \mathrm{mg} \mathrm{dw}$ ) are close to the theoretical minimum estimate of $\mathrm{dr} / \mathrm{dg}$ for 'normally' growing animals, whereas those for juvenile fish (body mass: $10^{3}$ to $10^{4} \mathrm{mg} \mathrm{dw}$ ) are generally higher. Even if the synthesis of ATP from oxidative phosphorylation runs at only $2 / 3$ its maximum efficiency (the lower likely limit), some of the published values of $\mathrm{dr} / \mathrm{dg}$ for juvenile fish are still well beyond the theoretical estimate. The implication is that SDA in juvenile (large) fish is not due solely to the costs of transport and net biomass formation, whereas these seem to be the main components of SDA in small aquatic organisms.

The cost of deamination is considered in the above calculations and the cost of digestion, urea formation as well as the cost of the mechanical work required to 
transport food down the gut are considered of minor quantitative importance (Tandler \& Beamish 1979, Kiørboe et al. 1985) in the overall cost of growth. Thus, the most likely additional component of SDA is increased rate of turnover (i.e. turnover synthesis) (cf. Jobling 1985). It is likely that turnover synthesis, like net biomass formation, increases with increasing food intake and that it is insignificant in comparison to net biomass synthesis in small organisms with a high specific growth rate and a low biomass to be turned over. These considerations predict that $\mathrm{dr} / \mathrm{dg}$ will increase with increasing body mass, an hypothesis which is supported by the scarce information available. However, this is in contrast to Jobling (1985) who claimed that SDA is specifically related to growth and that 'subjects that are growing slowly ... show little or no increase in metabolic rate following feeding'. Although Jobling considered turnover synthesis, he considered it to be an implication of growth rather than a result of food intake and body mass, i.e. the ratio of deposition to synthesis, or $\mathrm{dr} / \mathrm{dg}$, is constant and independent of body mass.

Direct determinations of rates of synthesis and deposition are few in fish. The only attempt we know of is that of Rosenlund et al. (1984). They estimated, however, that the specific rate of muscle protein synthesis was about an order of magnitude less than the observed specific growth rate. Experiments with homeothermic animals may be more informative. In growing, well-nourished (high protein diet) rats, there was a linear relation between muscle growth and muscle protein turnover, whereas in malnourished (low protein diet) but growing rats, turnover was independent of growth (Millward et al. 1975). In pigs, Reeds et al. (1980) found that whole body protein turnover increased with increasing ingestion of proteins and that the ratio of deposited to synthesized protein declined with body mass (constant specific ration; synthesis corrected for maintenance synthesis).

To the extent that this information is representative for fish, it suggests that (1) turnover of body constituents is not an implication of growth, (2) turnover synthesis increases with feeding level and (3) the ratio of synthesized to deposited proteins - and, hence, $\mathrm{dr} / \mathrm{dg}$ - increases with increasing body mass/age.

\section{CONCLUSIONS}

Herring larvae, and probably fish larvae in general, are very efficient in transforming assimilated energy into growth. Since $d r / d g$ has a theoretical minimum value $(\sim 0.11)$ it follows from Eqs. 9 \& 10 that the efficiency of growth ( $\mathrm{dg} / \mathrm{da}$ ) has a theoretical maximum $(\sim 0.9)$. Our 2 estimates of $\mathrm{dg} / \mathrm{da}(0.89$ and 0.91$)$ sug- gest that growth in herring larvae runs near the theoretical maximum.

The available evidence suggest that the apparent cost of growth is low and the efficiency of growth high in larval compared to juvenile fish. Although the evidence is somewhat conflicting, it is also suggested that cost and efficiency increase and decline, respectively, with body mass in fish. These trends are not necessarily causally related to body mass per se. In the present study, we found no change in growth efficiency related to body mass over a 2 order of magnitude variation in body mass. Variations in growth efficiency ( $\mathrm{dg} / \mathrm{da})$, apparent cost of growth (dr/dg) and feeding-induced turnover may instead be related to the potential for growth: organisms geared to a high potential growth rate may channel assimilated energy into growth rather than utilize the energy for increased turnover of body constituents, whereas organisms with a lower growth potential may have a different 'priority'. In the present experiments, growth potential (i.e. max. specific growth rate) was largely unrelated to body mass over the experimental range of body masses. In general, however, specific growth rates decline with age/body mass (e.g. Medaware 1941).

In an ecological or evolutionary context, juvenile and larval fish should give growth high priority. Specific mortality rates of pelagic fish decline with size (e.g. Peterson \& Wroblewski 1984), and large body size thus provides refuge from (predation) mortality. Accordingly, it has long been recognized that instantaneous growth and mortality rates are positively intercorrelated among fish (e.g. Beverton \& Holt 1959, Ware 1975). McGurk (1986) reviewed natural mortalities of marine, pelagic fish larvae. He found that mortalities of fish larvae were nearly an order of magnitude higher than expected from the trend of mortality and body mass in juvenile fish and that the decline in mortality with body mass was much steeper. Thus, natural selection would, in particular, favour high growth rates in fish larvae. Since growth in larvae is often limited by food in nature (e.g. Kiørboe \& Johansen 1986), an efficient transformation of assimilated material to body mass should also be favoured by natural selection. Apparently, fish larvae have achieved maximum efficiency of food conversion, which is limited only by the unescapable, biochemical cost of biomass formation.

\section{LITERATURE CITED}

Abou Debs, C. (1984). Carbon and nitrogen budget of the calanoid copepod Temora stylfera: effect of concentration and composition of food. Mar. Ecol. Prog. Ser. 15: 213-223

Ashworth, A. (1969). Metabolic rates during recovery from protein-caloric malnutrition: the need for a new 
concept of specific dynamic action. Nature, Lond. 223 : $407-409$

Berggren, U., Hansen, B. (1987). Partikelgrasning og vækststrategi hos den calanoide copepod Acartia tonsa. Master thesis, Univ, of Copenhagen

Beverton, R. J. H., Holt, S. J. (1959). A review of the lifespans and mortality rates of fish in nature and their relation to growth and other physiological characteristics. In: Wolstenholme, G. E. W., O'Connor, M. (ed.) The lifespan of animals. CIB.A Foundation Colloquia on Ageing, Vol. 5. Little, Brown and Co., Boston, p. 142-177

Birkett. L. (1969). The nitrogen balance in plaice, sole and perch. J. exp. Biol. 50: 375-386

Boehlert, G. W., Yoklavich, M. M. (1984), Carbon assimilation as a function of ingestion rate in Pacific herring. Clupea harengus pallasi Valenciennes. J. exp. mar. Biol. Ecol. 79: 251-262

Checkley, D. M., Jr. (1984). Relation of growth to ingestion for larvae of Atlantic herring, Clupea harengus, and other fish. Mar. Ecol. Prog. Ser. 18: 215-224

Erlich, K. F. (1974). Chemical changes during growth and starvation of herring larvae. In: Blaxter, J. H. S. (ed.) The early life history of fish. Springer-Verlag, New York, p. $301-323$

From, J., Rasmussen, G. (1984). A growth model, gastric evacuation, and body composition in rainbow trout, Salmo gairdneri Richardson, 1836. Dana Rep. 3: 61-139

Gerking, S. D. (1971). Influence of rate of feeding and body weight on protein metabolism of bluegill sunfish. Physiol. Zool. 44: 9-19

Govoni, J, J., Boehlert, G. W., Watanabe, Y (1986). The physiology of digestion in fish larvae. Environ. Biol. Fish. 16: $59-77$

Grisolia, S., Kennedy, J. (1966). On specific dynamic action, turnover, and protein synthesis. Perspect. Biol. Med. 9: $578-585$

Hogendoorn, H. (1983). Growth and production of the African catfish. Clarias lazera (C \& V). III. Bioenergetic relations of body weight and feeding level. Aquaculture 35 : $1-17$

Jobling, M. (1981). The influence of feeding on the metabolic rate of fishes: a short review. J. Fish Biol. 18: $385-400$

Jobling, M. (1983). Towards an explanation of specific dynamic action. J. Fish Biol. 23: 549-555

Jobling, M. (1985). Growth. In: Tytler, P., Calow, P. (ed.) Fish energetics: new perspectives. Croom Helm, London, p. $213-230$

Jørgensen, C. B. (1976). Growth efficiencies and factors controlling size in some mytillid bivalves, especially Mytilus edulis L.: review and interpretation. Ophelia 15: 175-192

Kibboe, T., Johansen, K. (1986). Studies of a larval herring (Clupea harengus L.) patch in the Buchan area. IV. Zooplankton distribution and productivity in relation to hydrographic features. Dana Rep. 6: 37-51

Kiorboe, T., Mohlenberg, F. (1987). Partitioning of oxygen consumption between 'maintenance' and 'growth' in developing hening embryos, Clupea harengus (L.). J. exp. mar. Biol. Ecol. (in press)

Kiørboe, T., Mohlenberg, F., Hamburger, K. (1985) Bioenergetics of the planktonic copepod Acartia tonsa relation between feeding, egg production and respiration, and composition of specific dynamic action. Mar Ecol. Prog. Ser. 26: 85-97

Kiorboe, T., Munk, P. (1986). Feeding and growth of larval herring, Clupea harengus, in relation to density of copepod nauplii. Environ. Biol. Fish. 17: 133-139

Lampert, W. (1986). Response of the respiration rate of Daphnia magna to changing food conditions. Oecologia (Berl.) 70: 495--501

McGurk, M. D. (1986). Natural mortality of marine pelagic fish eggs and larvae: role of spatial patchiness. Mar Ecol. Prog. Ser. 34: 227-242

Medaware, P. B. (1941). The 'laws' of biological growth Nature, Lond. 148: 772-774

Millward, D. J., Garlich, P. J., Stewart, R. J. C., Nnanyelugo, D. O., Waterlow, J. C. (1975). Skeletal-muscle growth and protein turnover. Biochem. J. 150: 235-243

Müller, H. L. von, Kirchgessner, M. (1979). Zur Energetik der Proteinsynthese beim Wachstum. Z. Tierphysiol., Tierernährg. u. Futtermittelkde. 42: 161-172

Munk, P., Kiorboe, T. (1985). Feeding behaviour and swimming activity of larval herring (Clupea harengus) in relation to density of copepod nauplii. Mar. Ecol. Prog. Ser 24: $15-21$

Munk, P., Rosenthal, H. (1983). Variability in the size of herring larvae at hatching. Influence of egg density and parental material. Int. Coun. Explor. Sea C.M. 1983/L: 33

Paloheimo, J. E., Dickie, L. M. (1966). Food and growth of fishes. III. Relations among food, body size, and growth efficiency. J. Fish. Res. Bd Can. 23: 1209-1248

Peterson, I., Wroblewski, J. S. (1984). Mortality rate of fishes in pelagic ecosystems. Can. J. Fish. Aquat. Sci. 41 : $1117-1120$

Reeds, P. J., Cadenhead, A., Fuller, M. F., Lobley, G. E. McDonald, J. D. (1980). Protein turnover in growing pigs. Effects of age and food intake. Br. J. Nutr. 43: 445-455

Rosenlund, G., Lund, B., Sandnes, K., Braekkam, O. R., Decken, A von der (1984). Muscle protein synthesis in vitro of saithe (Pollachius virens) correlated to growth and daily energy intake. Comp. Biochem. Physiol. 77B $7-13$

Siwicki, A. (1984). New anaesthetic for fish. Aquaculture 38 $171-176$

Smith, K. J. (1973). Energy transformation by saragassum fish, Histrio histrio (L.). J. exp. mar. Biol. Ecol. 12 : 219-227

Soofiani, N. M., Hawkins, A. D. (1982). Energetic cost at different levels of feeding in juvenile cod, Gadus morhua L. J. Fish Biol. 21: 577-592

Støttrup, J. G., Richardson, K., Kirkegaard, E. Pihl, N. J. (1986) The cultivation of Acartia tonsa Dana for use as a live food source for marine fish larvae. Aquaculture 52: 87-96

Stouthamer, A. H. (1973). A theoretical study on the amount of ATP required for synthesis of microbial cell material. Antonie van Leeuwenhoek 39: 545-565

Tandler, A., Beamish, F. W. H. (1979). Mechanical and biochemical components of specific dynamic action in large mouth bass, Micropterus salmoides Lacépède. J. Fish Biol. 14: 343-350

Tandler, A., Beamish, F. W H. (1981). Apparent specific dynamic action (SDA), fish weight and level of caloric intake in largemouth bass, Micropterus salmoides Lacepede. Aquaculture 23: 231-242

Vahl, $0 .(1984)$. The relation between specific dynamic action (SDA) and growth in the common starfish, Asterias rubens L. Oecologia (Berl.) 61: 122-125

Ware, D. M. (1975). Relation between egg size, growth, and natural mortality of larval fish. J. Fish. Res. Bd Can. 32: $2503-2512$ 